\title{
AKTUALISASI NILAI-NILAI PANCASILA TERHADAP HAK ATAS KEBEBASAN BERAGAMA DAN BERIBADAH DI INDONESIA
}

\author{
Sekar Anggun Gading Pinilih, Sumber Nurul Hikmah \\ Fakultas Hukum Universitas Diponegoro \\ Jalan Prof. Soedarto, SH, Tembalang Semarang \\ sekar anggun@live.undip.ac.id
}

\begin{abstract}
Indonesia is a religious pluralism country, not only one religion is recognized by the state but more than one religion and belief. Every Indonesian people has the freedom to choose and embrace religion or his belief without interruption and disturbing from others. This paper will be discussed what the manisfestation of values of Pancasila in Indonesia, and actualization of the values of Pancasila in guarantee the right for religious and worship. Pancasila comes as a unifying nation in running the diversity, especially the value of Belief in God. This value then animates Article $28 E$ Paragraph (1) and Article 29 of the Constitution of Indonesia as the legal basis for guarantee the right of religion and worship freedom.
\end{abstract}

Keywords: Pancasila, Religious and Worship Freedom, Indonesia

\begin{abstract}
Abstrak
Indonesia merupakan negara dengan pluralisme agama, dimana tidak hanya satu agama saja yang diakui oleh negara, tetapi lebih dari satu agama beserta kepercayaan, Artinya, setiap orang Indonesia memiliki kebebasan untuk memilih, memeluk, mengajarkan agama sesuai keyakinannya tanpa gangguan dan tanpa mengganggu agama orang lain. Penulisan ini akan membahas mengenai apa saja pengejawantahan nilai-nilai Pancasila di Indonesia, dan aktualisasi nilai-nilai Pancasila dalam menjamin hak atas kebebasan beragama dan beribadah di Indonesia. Pancasila hadir sebagai pemersatu bangsa dalam menjalankan keberagaman tersebut, utamanya nilai Ketuhanan Yang Maha Esa. Sila ini yang kemudian menjiwai Pasal 28 E ayat (1) dan Pasal 29 UUD NRI Tahun 1945 sebagai dasar hukum dalam menjamin hak atas kebebasan beragama dan beribadah di Indonesia.
\end{abstract}

Kata kunci: Pancasila, Kebebasan Beragama dan Beribadah, Indonesia

\section{A. Pendahuluan}

Pancasila sebagai dasar ideologi negara serta sekaligus dasar filosofis negara, sehingga setiap materi muatan peraturan perundang-undangan tidak boleh bertentangan dengan nilai-nilai yang terkandung dalam Pancasila. Pada sila pertama Pancasila berbunyi: "Ketuhanan Yang Maha Esa" mengandung nilai bahwa setiap orang Indonesia bertuhan menurut agama dan kepercayaannya, menjalanakan agama dan kepercayaan secara berkeadaban serta saling menghormati, dan segenap agama dan kepercayaan mendapat tempat dan perlakuan yang sama (Sekretariat Jenderal
MPR RI, 2014a). Artinya, setiap orang Indonesia memiliki kebebasan untuk memilih, memeluk, mengajarkan agama sesuai keyakinannya tanpa gangguan dan tanpa mengganggu agama orang lain atau menodakan agama.

Indonesia merupakan negara dengan pluralisme agama, dimana tidak hanya satu agama saja yang diakui oleh negara, tetapi lebih dari satu agama beserta kepercayaan. Namun, di tengah pluralisme agama, hubungan lintas agama di Indonesia semakin terpuruk. Hal ini dapat dilihat dari berbagai aksi kekerasan atas nama agama semakin meningkat belakangan ini. Peristiwa 
pembakaran rumah ibadah di beberapa daerah, penodaan agama Islam oleh Gubernur Jakarta Basuki Tjahaya Purnama, aksi damai bela Islam 212, serta keinginan penerapan sistem Khilafah oleh ormas Islam Hizbut Tahrir Indonesia di awal tahun 2017 merupakan gambaran terpuruknya hubungan lintas agama yang menimbulkan ketegangan dan berujung pada perpecahan persatuan antar umat beragama.

Kenyataan memprihatinkan di tengah masyarakat dapat terbaca bahwa belum semua pemeluk agama sadar dan bersikap cerdas menjunjung tinggi demokratisasi dan humanitas dalam pluralisme agama. Masih ada komunitas beragama yang terseret pada sikap eksklusif, mengutamakan klaim kebenaran (truth claims), arogansi etnis dan utamanya keserakahan kekuasaan, dendam dan friksi-friksi politik yang dibenarkan melalui pola manipulasi doktrin agama (Faqih, 2011a). Oleh karena itu, toleransi antarumat beragama perlu diupayakan kembali sesuai cita hukum demi menjaga keutuhan Negara Kesatuan Republik Indonesia.

Berdasarkan latar belakang tersebut, penulis tertarik untuk menulis permasalahanpermasalahan sebagai berikut:

1. Apa saja pengejawantahan nilai-nilai Pancasila di Indonesia?

2. Bagaimana aktualisasi nilai-nilai Pancasila dalam menjamin hak atas kebebasan beragama dan beribadah di Indonesia?

Penulisan ini menggunakan pendekatan perundang-undangan dan pendekatan konsep serta teori yang berkaitan dengan permasalahan yang dikaji.

\section{B. Pembahasan \\ 1. Pengejawantahan Nilai-Nilai Pancasila di Indonesia}

Pancasila merupakan norma dasar (grundnorm) menurut Hans Kelsen dan $\mathrm{n}$ orm a funda me n a 1 negara (staatsfundamentalnorm) menurut Hans Nawiasky. Menurut Soekarno Pancasila merupakan filosofische grondslag, yaitu sebagai fundamen, filsafat, pikiran yang mendalam. Pancasila merupakan pemersatu bangsa dan pandangan hidup (way of life), sehingga Pancasila sebagai dasar dan ideologi negara serta sekaligus dasar filosofis negara, maka setiap materi muatan peraturan materi muatan peraturan perundang-undangan tidak boleh bertentangan dengan nilai-nilai yang terkandung dalam Pancasila (Sekretariat Jenderal MPR RI, 2014b).

Pancasila merupakan sumber dari segala sumber hukum negara, sehingga dalam penyelenggaraan kekuasaan negara yang berdasarkan atas hukum, Pancasila harus selalu dijadikan rujukan dalam pembangunan hukum. Adapun sumber-sumber Pancasila sebagai dasar negara antara lain nilai keagamaan, adat istiadat, kebudayaan, nilainilai yang hidup dalam masyarakat, dan perkembangan ideologi dunia pada saat itu (Sekretariat Jenderal MPR RI, 2014c).

Dalam kedudukannya sebagai dasar dan ideologi negara yang tidak dipersoalkan bahkan kuat, maka Pancasila itu harus dijadikan paradigma (kerangka berpikir, sumber nilai, dan orientasi arah) dalam pembangunan hukum, termasuk semua upaya pembaharuannya. Pancasila sebagai dasar negara memang berkonotasi yuridis, dalam arti melahirkan berbagai peraturan perundangan yang tersusun secara hierarkis dan bersumber darinya, sedangkan Pancasila sebagai ideologi dapat dikonotasikan sebagai program sosial politik, tempat hukum menjadi salah satu alatnya, dan karenanya juga harus bersumber darinya (Mahfud MD, 2010a).

Sebagai paradigma pembangunan hukum, Pancasila memiliki sekurangkurangnya empat kaidah penuntun yang harus dijadikan pedoman dalam pembentukan dan penegakan hukum di Indonesia. Pertama, hukum harus melindungi segenap bangsa dan menjamin keutuhan bangsa dan karenanya tidak diperbolehkan ada hukum-hukum yang menanam benih disintegrasi. Kedua, hukum harus mampu menjamin keadilan sosial dengan memberikan proteksi khusus bagi golongan lemah agar tidak tereksploitasi dalam persaingan bebas melawan golongan yang kuat. Ketiga, hukum harus dibangun secara demokratis sekaligus membangun demokrasi sejalan dengan nomokrasi (negara hukum). Keempat, hukum tidak boleh diskriminatif berdasarkan ikatan primordial apapun dan harus mendorong terciptanya toleransi beragama berdasarkan kemanusiaan 
dan keberadaban(Mahfud MD, 2010b).

Adapun nilai-nilai yang terkandung dalam Pancasila antara lain:

a. Ketuhanan Yang Maha Esa, mengandung nilai antara lain:

1) Setiap orang Indonesia bertuhan menurut agama dan kepercayaannya.

2) Menjalankan agama dan kepercayaan secara berkeadaban serta saling menghormati.

3) Segenap agama dan kepercayaan mendapat tempat dan perlakuan yang sama.

Pada sila pertama tersebut menunjukkan bahwa Negara Indonesia mengakui pluralisme agama di Indonesia, artinya tidak hanya satu agama saja yang diakui, sehingga antar umat beragama harus saling menghormati dan menghargai hubungan sosial lintas agama. Setiap orang memiliki hak dan kebebasan untuk memilih, memeluk, dan mengajarkan agama tanpa gangguan dan tanpa mengganggu agama maupun kepercayaan orang lain. Kemajemukan agama itu harus tetap dalam bingkai akhlak untuk membangun dan memberdayakan relasi inklusifitas persaudaraan dan kebersamaan antar pemeluknya, bukan relasi yang menyuburkan persinggungan dan ketegangan. Masingmasing pemeluk agama harus menghargai dan mengadvokasi hak humanitas sesamanya dalam beragama(Faqih, 2011b).

b. Kemanusiaan Yang Adil dan Beradab, mengandung nilai antara lain :

1) Perlakuan terhadap manusia secara adil, tidak memihak, dan berpegang kepada kebenaran.

2) Beradab maksudnya berbudi luhur, sopan, dan bersusila.

Setiap sila pada hakikatnya merupakan suatu asas sendiri seingga memiliki fungsi sendiri-sendiri, namun secara keseluruhan merupakan suatu kesatuan yang sistematis (Herawati, 2015), dan saling menjiwai, maka sila kedua ini dijiwai oleh sila pertama dan menjiwai sila ketiga, keempat, dan kelima. Pada sila kedua ini menunjukkan bahwa dalam kehidupan berbangsa dan bernegara setiap orang harus mendapatkan perlakuan yang sama tanpa melihat suku, bangsa, agama, maupun ras. Hakim dalam menjatuhkan hukuman harus dengan keadilan yang tidak memihak serta memutus yang benar adalah benar dan yang salah adalah salah. Konsep ini sesuai dengan konsep negara hukum. Selain itu, dengan keadilan maka dapat memberikan jaminan perlindungan hak asasi manusia. Setiap orang harus menjunjung tinggi harkat dan martabat orang lain karena dengan menghargai orang lain sama artinya dengan menghargai diri sendiri. Dalam kehidupan berbangsa dan bernegara harus menjaga etika dan sopan santun untuk menjadi manusia yang beradab.

c. Persatuan Indonesia, mengandung nilainilai antara lain:

1) Persatuan dalam arti luas

2) Melindungi segenap bangsa

3) Bersatu dalam keberagaman

Di tengah konflik agama dalam masyarakat antar umat beragama saat ini telah memicu adanya perpecahan persatuan bangsa. Oleh karena itu, nilai-nilai sila ketiga memiliki peranan penting dalam menjaga persatuan serta melindungi segenap bangsa untuk dapat bersatu dalam keberagaman tanpa memandang latar belakang agama, suku, dan ras, serta menghimpun setiap perbedaan menjadi keberagaman dan berdampingan serta bersatu dalam kebhinekaan. Salah satu wujud dari persatuan adalah bentuk Negara Kesatuan Republik Indonesia, yakni hanya memiliki satu pemerintahan di dalam negara. Hal ini bertujuan untuk melindungi segenap bangsa yang beragam dan berdampingan dalam pluralisme.

d. Kerakyatan Yang Dipimpin Oleh Hikmat Kebijaksanaan dalam Permusyawaratan/Perwakilan, mengandung nilai-nilai antara lain:

1) Rakyat memiliki kedaulatan

2) Nilai demokrasi

3) Prinsip musyawarah

4) Rakyat memiliki perwakilan

Indonesia merupakan negara demokrasi dimana setiap pengambilan kebijakan bukan menjadi otoritas pemimpin. Melainkan dari rakyat, oleh rakyat dan untuk rakyat. Dalam menyelesaikan setiap persoalan harus mengedepankan nilai demokrasi yang dilakukan melalui musyawarah untuk mufakat. Dalam hal ini kebijakan pengambilan keputusan rakyat diwakili oleh perwakilan, baik oleh Dewan 
Perwakilan Rakyat maupun Dewan Perwakilan Daerah. Dewan Perwakilan Rakyat maupun Dewan Perwakilan Daerah Republik Indonesia dalam mengambil kebijakan harus mementingkan kepentingan rakyat daripada kepentingan pribadi.

e. Keadilan Sosial bagi seluruh rakyat Indonesia, mengandung nilai-nilai antara lain:

1)Perlakuan yang adil terhadap rakyat

2)Adil dalam segala aspek kehidupan

3)Perlindungan terhadap rakyat agar hidup sejahtera

Dalam kehidupan berbangsa dan bernegara, negara harus memperlakukan rakyat dengan adil, tidak berlaku sewenangwenang. Setiap kebijakan atau keputusan yang diambil adalah dalam rangka mewujudkan kesejahteraan rakyat, keadilan tanpa memihak serta adil sesuai dengan tugas dan wewenang, karena hukum tertinggi dalam suatu negara adalah kemakmuran dan kesejahteraan rakyat. Untuk mewujudkan welfare state ini dapat diwujudkan melalui perlakuan adil dalam segala aspek kehidupan tanpa melihat status sosial, kedudukan, agama, suku serta perlindungan kepada rakyat yang diwujudkan melalui programprogram pemerintahan, dimana tujuan dari penyelenggaraan negara adalah untuk memajukan kesejahteraan umum rakyat Indonesia secara keseluruhan. Sila kelima ini berkaitan erat untuk mewujudkan keadilan dan kesejahteraan rakyat(Redi, 2016).

Pancasila sebagai dasar falsafah negara menempatkan kepentingan pribadi dan kepentingan umum dalam posisi berimbang, karena posisi manusia ditinjau dari sudut subyektif dwi tunggal sebagai individu dan makhluk sosial. Dalam hal ini, antara kepentingan pribadi dan kepentingan umum tidak saling mengalahkan, namun satu sama lainnya merupakan keserasian (Andora, 2016).

Nilai-nilai Pancasila tersebut harus diimplementasikan dalam kehidupan bermasyarakat, berbangsa dan bernegara, karena nilai-nilai Pancasila sesuai dengan falsafah bangsa, maka apabila diterapkan dengan baik, dihayati, dan dijadikan pedoman setiap bangsa akan tercapai kemakmuran dan kesejahteraan, yakni masyarakat hidup berdampingan di dalam keragaman dalam bingkai Bhineka Tunggal Ika. Hal ini sesuai dengan cita hukum yakni hukum yang dicitacitakan oleh masyarakat, dan tujuan Negara Kesatuan Republik Indonesia yang tertuang dalam Pembukaan Undang-Undang Dasar Negara Kesatuan Republik Indonesia Tahun 1945 alinea ke empat.

\section{Aktualisasi Nilai-Nilai Pancasila Dalam Menjamin Hak Atas Kebebasan Beragama Dan Beribadah Di Indonesia}

Indonesia sebagai negara hukum dengan pluralisme agama wajib memberikan jaminan hak atas kebebasan beragama dan beribadah. Menurut Fatmawati(Fatmawati, 2011) bahwa Jaminan atas hak kebebasan beragama dan beribadah diatur dalam Pembukaan UndangUndang Dasar 1945 (UUD 1945) dan Batang Tubuh UUD 1945. Selain itu, diatur dalam berbagai peraturan perundang-undangan yakni Undang-Undang Nomor 39 Tahun 1999 Tentang Hak Asasi Manusia yang didasari TAP MPR Nomor XVII/MPR/1998 Tentang Pandangan Hidup Bangsa Indonesia tentang Hak Asasi Manusia dan Piagam Hak Asasi Manusia.

Perlunya pengaturan terhadap kehidupan beragama tidak hanya mengakomodasi golongan agama tertentu, akan tetapi karena hal tersebut harus diatur demi kepentingan ketertiban dalam masyarakat. Kasus yang biasanya terjadi dalam hubungan antar warga negara terkait kehidupan beragama adalah proselytism yang dilakukan dengan tidak etis, penodaan agama, dan penyalahgunaan agama. Proselytism tidak etis merupakan paksaan untuk berpindah dari agama satu ke agama yang lain.

Dalam pembahasan tentang konsep hak atas kebebasan beragama dan beribadah telah dituangkan dalam sila pertama Pancasila, yaitu Ketuhanan Yang Maha Esa yang mengandung nilai bahwa setiap manusia di Indonesia berkewajiban mengormati agama dan kepercayaan orang lain, sekalipun ia tidak mempercayai doktrin maupun ajaran agama dan kepercayaan tersebut karena setiap agama dan kepercayaan mendapat tempat dan perlakuan yang sama dan setiap orang berhak untuk memilih, memeluk dan mengamalkan ajaran-ajaran agama tersebut secara bebas 
tanpa gangguan maupun mengganggu pemeluk agama lain.

Di Indonesia, pemeluk agama Islam adalah mayoritas, maka berdasarkan nilai sila pertama Pancasila tersebut, pemeluk agama Islam tidak boleh memaksakan orang lain untuk memeluk agama Islam, dan antar pemeluk agama dan kepercayaan harus saling menghargai serta saling menghormati hak kebebasan beragama setiap orang. Dengan adanya saling menghargai dan menghormati, maka akan tercipta kerukunan dan persatuan, yakni bersatu dalam keberagaman sesuai dengan pengamalan sila kedua dan ketiga Pancasila. Dalam setiap ajaran agama tentu mengajarkan kebaikan dan kedamaian sehingga tidak dibenarkan dalam keadaan apapun untuk memaksakan seseorang berpindah agama. Islam sebagai agama mayoritas di Indonesia yang Rahmatan Lil 'Aalamiin terdapat konsep laa ikrohu fiddin, yang artinya tidak ada paksaan dalam beragama serta toleransi beragama di dalam Islam sangat tinggi, dimana dijelaskan dalam salah satu ayat Alqur'an Surat Al Kaafirun ayat 6 yang berbunyi lakum diinukum waliyadin, yang artinya bagimu agamamu dan bagiku agamaku. Ayat ini menggambarkan bahwa toleransi dalam beragama terdapat batasan yakni tidak dibenarkan antar umat beragama ikut melaksanakan ibadah agama dan kepercayaan lain, maka konsep ini dapat diterapkan dalam toleransi umat beragama di Indonesia.

Pancasila sebagai dasar falsafah negara terdapat dalam alinea keempat UUD NRI Tahun 1945 dengan sila pertama "Ketuhanan Yang Maha Esa" bukan saja menjadi dasar rohani dan dasar moral kehidupan bangsa, melainkan secara implisit juga mengandung toleransi beragama. Konsep hak atas kebebasan beragama dan beribadah yang didasarkan pada sila pertama Pancasila, yang kemudian menjiwai dari Pasal $28 \mathrm{E}$ ayat (1) dan Pasal 29 UUD NRI Tahun 1945. Toleransi beragama dalam hal ini menghargai agama dan kepercayaan orang lain, menghormati agama dan kepercayaan walaupun tidak mempercayai doktrin ajaran agamanya. Dalam hal toleransi beragama terdapat batasan yang harus dipahami oleh rakyat
Indonesia yaitu tidak mengikuti atau melaksanakan ajaran agama tersebut, namun cukup menghargai ajarannya, tidak menodakan atau mengganggu kegiatan ibadah agama dan kepercayaan lain tersebut. Toleransi beragama dalam kehidupan berbangsa dan bernegara telah dicontohkan dengan baik oleh ormas Islam dan Kristen, yakni dalam hal perayaan hari raya natal Banser Nahdlatul 'Ulama (NU) ikut menjaga keamanan gereja dari gangguan radikalis.

Indonesia adalah negara hukum yang dijiwai oleh Pancasila dalam penyelenggaraan kehidupan berbangsa dan bernegara, walaupun bukan merupakan negara agama juga bukan negara sekuler terlebih negara atheis, akan tetapi negara hukum yang terdapat hubungan erat antara negara dan agama, sehingga dalam hal ajaran agama yang memerlukan campur tangan negara harus diatur dalam peraturan perundang-undangan. Hak kebebasan beragama dan beribadah merupakan bagian dari hak-hak publik dan sipil, sehingga juga memerlukan peranan negara dalam hal pelaksanaannya, tidak hanya individual tapi kelompok, bahkan hubungannya dengan negara lain seperti penyelenggaraan ibadah haji.

Pengaturan dalam beragama diperlukan karena untuk menyeragamkan pelaksanaan ibadah tiap agama, namun negara pun menghargai adanya khilafiyah atau perbedaan pendapat dalam beragama, seperti organisasi Islam Muhammadiyah yang melaksanakan ibadah puasa sebelum tanggal ditetapkan dalam sidang Isbat Kementerian Agama Republik Indonesia. Pada dasarnya pengaturan ini adalah pengejawantahan dari nilai-nilai sila pertama bahwa dengan adanya pengaturan, maka akan menumbuhkan dan meningkatkan toleransi antar umat beragama karena adanya kekuatan hukum yang mengikat. Dalam kaitannya dengan jaminan atas kebebasan beragama dan beribadah, maka pemerintah harus lebih bersungguhsungguh dalam perbaikan pengaturan terkait kebebasan beragama agar tidak terjadi kekerasan dan penodaan agama maupun kepercayaan.

Agama memang dapat menjadi faktor perekat atau pemersatu, tetapi bukan 
penyatuan. Konsep pemersatu atau perekat bukanlah penyeragaman karena jika yang dimaksud adalah penyeragaman, maka inilah yang menjadi salah satu akar penyebab konflik. Konsep agama sebagai pemersatu lebih kepada semangat inklusifitas, toleransi, egaliterian, humanisasi yang diderivasi dari ajaran keagamaan. Oleh karenanya, agama harus mengedapankan apresiatif terhadap keragaman (pluralitas) (Sapendi, 2012). Dengan adanya apresiatif terhadap pluralitas, maka akan dapat terwujud rasa kemanusiaan yang beradab yang tinggi karena saling memperlakukan sesama manusia dengan adil, tidak memihak dan berpegang pada kebenaran serta hal ini mampu mendorong persatuan dan kesatuan bangsa, sehingga apabila terdapat permasalahan antarumat beragama dapat diselesaikan melalui musyawarah mufakat atau dengan kepala dingin. Hal ini untuk menghindarkan pada kasus penodaan agama yang dapat memecah belah persatuan dan kesatuan bangsa.

Dalam beragama penting untuk memahami ajaran agama secara maknawi, tidak hanya tekstual saja, sehingga dapat mentolerir ajaran agama lain yang berbeda dengan ajaran yang dianut. Indonesia berlandaskan Pancasila sebagai ideologi dan falsafah bangsa dibangun oleh pahlawanpahlawan dari berbagai agama, suku, bangsa, dan ras. Kemerdakaan Indonesia tercapai setelah perjuangan panjang dan melelahkan dengan motivasi yang tinggi untuk merdeka dan atas berkat rahmat Allah Yang Maha Kuasa telah mengantarkan Proklamasi Kemerdekaan (Fadlil Sumadi, 2015), yang selanjutnya membentuk Konstitusi. Dengan demikian, walaupun Indonesia pemeluk agama mayoritas adalah Islam tetap tidak bisa mengubah Indonesia menjadi sistem khilafah. Dikarenakan Indonesia tidak hanya terdiri dari pemeluk agama Islam saja tetapi implikasi dari nilai sila pertama Pancasila yakni setiap orang bertuhan dengan agama dan kepercayaannya, maka dalam hal ini tidak sesuai apabila diterapkan sistem khilafah. Dengan sistem khilafah akan hilang toleransi dalam umat beragama karena sendi-sendi penyelenggaraan pemerintahan akan berdasarkan Islam yang mana dalam hukum Islam berlaku bahwa darah selain orang Islam halal untuk dibunuh, maka hal ini akan sangat bertentangan dengan falsafah bangsa, ideologi bangsa Indonesia yakni Pancasila dan melanggar hak asasi manusia.

Pluralisme dalam kehidupan berbangsa dan bernegara merupakan aksioma yang tidak bisa dibantah dan merupakan keniscayaan sejarah yang bersifat universal, sehingga pluralitas agama harus dipandang sebagai bagian dari kehidupan manusia (Andi \& Fadilla, 2016), maka dalam menyikapi pluralisme agama harus mendasarkan atau menyesuaikan pada nilai-nilai Pancasila, utamanya nilai Ketuhanan Yang Maha Esa harus dihayati dan dijadikan pedoman dalam kehidupan berbangsa dan bernegara. Selain itu, hak atas kebebasan bearagama adalah hak asasi manusia yang wajib dan telah dijamin oleh negara, artinya tidak ada seorangpun yang dapat mengusik ataupun mengganggu ibadah agama setiap orang, karena setiap orang memiliki kebebasan untuk bertuhan menurut agama dan kepercayaan, setiap orang menjalankan agama dan kepercayaan secara berkeadaban serta saling menghormati, serta segenap agama dan kepercayaan mendapat tempat dan perlakuan yang sama.

Dengan menanamkan nilai Pancasila tersebut akan dapat mewujudkan rasa kemanusiaan yang beradab dan tercipta kehidupan bermsayarakat yang humanis karena tidak adanya konflik agama. Adanya rasa humanis dan kemanusiaan tersebut akan mendorong persatuan dan kesatuan bangsa, dalam hal ini apabila rakyat bersatu mempertahankan negara dan bela negara, maka negara akan kuat dari ancamanancaman luar yang ingin meruntuhkan Indonesia. Selain itu, dapat membantu negara untuk mencapai tujuan-tujuan negara sebagaimana tertuang dalam Pembukaan UUD 1945 alinea ke empat serta dapat mancapai cita hukum atau hukum yang dicitacitakan oleh rakyat Indonesia.

\section{Simpulan}

Berdasarkan pembahasan di atas, dapat ditarik simpulan sebagai berikut:

1. Pengejawantahan nilai-nilai Pancasila di Indonesia dijabarkan dalam tiap sila Pancasila, dimana sila satu dengan sila 
yang lain merupakan kesatuan yang sistematis. Artinya, tiap sila dalam Pancasila menjiwai sila-sila yang lain. Nilai-nilai tersebut harus dijadikan pedoman dan dihayati dalam setiap penyelenggaraan negara maupun dalam kehidupan sehari-hari serta setiap perbuatan tidak boleh bertentangan dengan Pancasila.

2. Aktualisasi nilai-nilai Pancasila dalam menjamin hak atas kebebasan beragama dan beribadah di Indonesia termaktub dalam Pancasila, utamanya sila pertama, Pasal 28 E ayat (1) dan Pasal 29 UUD NRI Tahun 1945. Setiap orang dijamin haknya atas kebebasan beragama dan beribadah sesuai dengan agama dan kepercayan. Setiap orang memiliki hak dan kebebasan untuk memilih, memeluk, mengamalkan ajaran agamanya dengan tanpa gangguan dan tidak mengganggu agama lain. Dengan pluralitas agama, maka setiap orang wajib menghargai dan menghormati agama dan kepercayaan orang lain.

\section{DAFTAR PUSTAKA}

Andi, A., \& Fadilla, E. (2016). Menyikapi Pluralisme Agama Perspektif Al Quran. Jurnal Esensia, 17(1), 43.

Andora, H. (2016). Aktualisasi Nilai-nilai Pancasila Dalam Pengadaan Tanah Bag i Pembangunan Untuk Kepentingan Umum. Jurnal MasalahMasalah Hukum, 45(2), 109.

Fadlil Sumadi, A. (2015). Hukum dan Keadilan Sosial dalam Perspektif Hukum Ketatanegaraan. Jurnal Konstitusi, 12(4), 853854.

Faqih, M. (2011a). Menegakkan Hak Beragama Di Tengah Pluralisme. Jurnal Konstitusi, 8(4), 438.Faqih, M. (2011b). Menegakkan Hak Beragama Di Tengah Pluralisme. Jurnal Konstitusi, 8(4), 434435.

Fatmawati. (2011). Perlindungan Hak Atas Kebebasan Beragama dan Beribadah Dalam Negara Hukum Indonesia. Jurnal Konstitusi, 8(4), 503.

Herawati, R. (2015). Implikasi Sistem Pengisian Keanggotaan Dewan
Perwakilan Daerah Republik Indonesia Terhadap Nilai-nilai Pancasila. Jurnal Masalah-Masalah Hukum, 44(4), 396.

Mahfud MD, M. (2010a). Membangun Politik Hukum, Menegakkan Konstitusi. Jakarta: Rajawali Pers.

Mahfud MD, M. (2010b). Membangun Politik Hukum, Menegakkan Konstitusi. Jakarta: Rajawali Pers.

Redi, A. (2016). Kontrak Karya PT Freeport Indonesia dalam Perspektif Pancasila dan UUD NRI 1945. Jurnal Konstitusi, 13(3), 624625.

Sapendi. (2012). Pendidikan Plurisme Agama (Membangun Hubungan Sosial Lintas Agama Di Sekolah). Jurnal Khatulistiwa-Journal of Islamic Studies, 2(2), 156.

Sekretariat Jenderal MPR RI. (2014a). Bahan Tayang Materi Sosialisasi Pancasila, UUD NRI Tahun 1945, NKRI dan Bhineka Tunggal Ika. Jakarta.

Sekretariat Jenderal MPR RI. (2014b). Bahan Tayang Materi Sosialisasi Pancasila, UUD NRI Tahun 1945, NKRI dan Bhineka Tunggal Ika. Jakarta.

Sekretariat Jenderal MPR RI. (2014c). Bahan Tayang Materi Sosialisasi Pancasila, UUD NRI Tahun 1945, NKRI dan Bhineka Tunggal Ika. Jakarta. 